A Research on Externalities in Transportation Sector

\author{
Meserret NALÇAKAN○ \\ Eskisehir Technical University, Vocational School of Transportation, Department of \\ Transportation Services, Eskişehir, Turkey. \\ mnalcakan@eskisehir.edu.tr
}

(Alinış/Received: 20.05.2020, Kabul/Accepted: 06.07.2020, Yaylmlama/Published: 31.07.2020)

\begin{abstract}
Transportation activities have a significant role in the service sector. Transportation has led to major changes in the history of human development, economically, socially, culturally and politically. With the growth both in freight capacity and in the number of passengers, along with the boosting effect of the increased transportation speed, the developments in transportation services paved the way for globalization. While being carrying out, transportation services, besides many desirable outcomes, cause adverse effects faced by individuals and society; in other words, lead to the problem of externality. Externality is considered as the cost that needs to be eliminated when the producers or consumers do not bear all the consequences, or when they do not take into account the effects they reflect on a third party, of their behaviors. In this study, it is aimed to determine externalities identified as negativities occurring during the transportation services, to examine the economic effects of externalities, and to discuss the methods on internalizing externalities.
\end{abstract}

Keywords: Transportation, Externalities, Internalization of Externalities, Globalization.

\title{
Ulaştırma Sektöründe Dışsallıklar Üzerine Bir Araştırma
}

Öz: Ulaştırma faaliyetlerinin hizmet sektörü içinde çok önemli yeri bulunmaktadır. Ulaştırma, insanlığın gelişim tarihinde ekonomik, toplumsal, kültürel ve politik yönden önemli değişikliklerin yaşanmasına yol açmışıtır. Taşınan yük kapasitesi ve yolcu sayısındaki artışla birlikte taşıma hızındaki artışın da etkisiyle ulaştırma hizmetlerindeki gelişmeler küreselleşmeyi beraberinde getirmiştir. Ulaştırma hizmetleri, pek çok olumlu etkisinin yanında söz konusu hizmetlerin gerçekleştirilmesi sürecinde bireylerin ve toplumun maruz kaldığı olumsuzlukların; başka bir söyleyişle dışsallık sorununun yaşanmasına yol açmaktadır. Dışsallık; üretici ya da tüketicilerin davranışlarının bütün sonuçlarına katlanmadıkları; başkaları üzerindeki etkilerini hesaba katmadıklarında beliren ve söz konusu etkilerinin ortadan kaldırılması gereken bir maliyet unsuru olarak ele alınmaktadır. Bu çalışmada, ulaştırma hizmetlerinin sunulması esnasında ortaya çıkan olumsuzluklar şeklinde tanımlanan dışsallıkların belirlenmesi, dışsallıkların ekonomik etkilerinin irdelenmesi ve dışsallıkların içselleştirilmesiyle ilgili yöntemlerin ele alınması amaçlanmaktadır.

Anahtar kelimeler: Ulaştırma, Dışsallıklar, Dışsallıkların içselleştirilmesi, Küreselleşme.

\section{Introduction}

The developments observed in health, education, communication and transport sectors have always played a considerable role in the overall development of societies.

When new technologies are examined from a macroeconomic point of view, the countries are observed to have relatively higher competitive power and welfare and development levels providing that they increase their use of information technologies.

From a micro economic point of view, on the other hand, how much information technology is used affects producers' ability to activate their strategic management mechanisms and their competitive power. 


\section{Demiryolu Mühendisliği}

In today's world, Information Technologies, which are considered the basic input for information economy, have contributed a lot to the development of transport technology. This situation, therefore, has resulted in certain new trends in production practices as well as a new competition structure in the market and has strengthened the already existing development potential of the sector.

The improvements in transport infrastructure and the use of new technologies in transport vehicles have resulted in a new situation affecting all units of economy and, therefore, required the initiation of a restructuring process as a must condition of information economy. The fact that information technologies have improved and made it possible to establish effective communication and network systems has led to a considerable increase in competitive power and the development of marketing, distribution and introduction practices in transport sector. Transport sector considerably differs from other sectors of economy such as agriculture, industry and other service sectors. These differences can be summarized as follows [1]:

- Transport is a technology-based engineering industry.

- Transport is an indispensable component of everyday life. In other words, transport is an industry typically creating externalities more than any other sector.

- Transport is quite interrelated with other sectors. So, it both affects and is affected by other sectors.

\section{The Effects of Globalization on Transport Sector}

The basic components of transport include vehicles, environment, infrastructure and individuals. Based on this approach, "costs" can be defined as "the problems occurring due to interactions both within and among these components [2].

In order to determine accurately how demands can be fulfilled by creating the lowest cost possible and by using the most convenient transport means, social and environmental costs created by transport means as well as building, maintenance/fixing and operation costs should be included in the overall cost. The cost-based approach, in which externalities are internalized, plays a significant role in establishing a mutual coordination and efficiency in using resources. This approach is also necessary for the effectiveness in consumption/ allocation practices and makes it possible to include service costs in the price [3].

\section{Concept of Externality and Externalities Created by Transportation}

Since a broader range of demands and needs by individuals means broader range of services and activities in production sector, this situation leads to the emergence of externalities in the form of environmental problems as the consequences of consumption. The increase in environmental costs creates negative externalities, and the awareness that environment is a limited resource now and will continue to be so in the future requires the authorities to take urgent precautions as soon as possible.

The expanding world trade thanks to the developments in technology, transport and communication as well as new financial trends due to financial freedom observed in international capital markets and other factors - such as the international mobility of individuals and goods - leads to external effects on economy, environment, health and society in various ways.

The products by a specific producer might be dependent not only on the input used by this producer but also on the practices of other producers, which results in "exogenous saving" or 


\section{Demiryolu Mühendisliği}

"external diseconomies". In other words, these two terms refer to any benefits (services) or loss created on other producers without giving or receiving something in return [4].

"Externalities", "external factors" or "external economy" and "external minus economies" are the different names used for the specific concept proposed firstly by Alfred Marshall. According to the most commonly agreed definition, externalities are observed when certain costs are created on others without compensating for these costs or when certain benefits are provided to others without receiving anything in return. In short, externalities are unpaid mutual links among economic units. From a different point of view, externalities occur when economic units do not pay for the price for their actions and they ignore their effects on others during their actions [5].

Herman Daly, the intellectual pioneer of rapidly growing ecological economy, states that world is experiencing a transition from a phase, when human-based capital was the restricting element in economic development, to another phase when an increasingly scarce natural capital exists. In the past, when human population was relatively low in comparison with the vast area of the earth, human-based capital was scarce while natural capital was abundant. Now, this situation has shifted. While human enterprises increase, the services and opportunities provided by "ecosystem" are decreasing. Therefore; when human-based capital is abundant, natural capital is getting more and more restrictive [6].

The most commonly observed externalities in transport sector are due to the negative effects of insufficient infrastructure, vehicle technology and energy resource used as well as poor service quality on human beings and environment. Since the awareness about environmental issues has considerably increased recently, the concept "externalities" is, now, quite significant in transport sector and assumes a primary role in determining the priorities of the related sub sectors.

The main objectives of sustainable transport can be listed as follows: establishing the transport infrastructure in a way to ensure economic development; providing healthier and safer transport alternatives; reducing externalities; extending transport services to large masses in the society; and listening to various democratic voices during policy development processes regarding transport sector. The scope of "sustainable transport can be classified into three groups: namely economic, ecological and social [7].

"Economic sustainable transport refers to cost-efficient transport structure. Accordingly, transport sector should keep up with continuously changing demand structure as quickly as possible and certain economic elements such as productivity, economic activities, employment, taxation and trade should be taken into consideration during this process.

Ecologically sustainable transport, on the other hand, aims at keeping emissions and resource use at a reasonable level during transport services so as not to give permanent harm to ecosystem in the future. Ecological sustainability deals with certain issues such as pollution emissions, climate change, biological diversity, preservation of habitat and aesthetics.

Socially sustainable transport is all about meeting social needs fairly. In this context, justice, life quality, cultural, historical and public relations are among the issues "socially sustainable transport" deals with.

In transport sector, local, regional, national and international transport services are provided by the following subsectors; namely air, road and sea transport. It is no doubt that all these subsectors create their own particular externalities. 


\section{Demiryolu Mühendisliği}

Although transport contributes a lot to economic and social development, it is the main consumer of non-renewable resources such as energy. In addition, transport creates costs not only for the individuals using this service but also for the other members of the society by causing environmental pollution and affecting human health negatively. All these costs are called "social costs of transport", which are classified into two groups [8]:

- The costs that have to be paid by those receiving transport services called "internal / special costs": fuel, energy, cost of vehicle, ticket fee, tolls, fuel tax and insurance etc.

- External costs occur when a transport customer affects the welfare of another group negatively without paying any compensation for that harm. For instance, lorries cause air and noise pollution which negatively affect the people dwelling in the areas on their routes.

When transport externalities are classified in terms of the effects created, in-sector externalities for those who are affected are listed as traffic jam, the harms given to infrastructure and accidents while inter-sectoral ones are reported to be noise and environmental pollution. Finally, according the classification type based on resources, the externalities occur due to vehicle use in the city center and demands for parking lots. Since those involved in transport activities are directly affected by in-sector externalities, the effects of such externalities on the other members of the society are indirect. Among such in-sector externalities are transport infrastructure costs, transport service costs, unforeseen costs due to delays or repairs etc, traffic accidents and traffic jam. Although transport externalities occur at various levels and in quite different ways, it is possible to examine such externalities in four main groups in terms of how they occur [7].

"Transport externalities observed at the first level occur when environmental and human resources are consumed in a way such resources cannot be renewed or the costs for the damage given during this provision and consumption are not compensated. Air pollution and water contamination due to transport activities can be given as examples to such externalities.

Second-level externalities are related to the financing of transport infrastructure. If public sector cannot finance transport infrastructure through the payments made by the customers using this service, "external economy" can be applied to provide the amount which is required for this compensation. Among such externalities are "wear-outs" in transport infrastructure and transport service costs.

Third level transport externalities; on the other hand, occur when the customers of transport service use this service all together at a certain time and duration. In such a situation, an external cost called "traffic jam" is to occur since it is not possible to increase the capacity of transport infrastructure immediately when the problem occurs.

Finally, fourth level transport externalities refer to what transport sector can offer to manufacturers and consumers. Such effects are the outcomes of the interactions between transport sector, production and consumption sectors. Economists do not agree on the externalities listed in this category. Some do not define such interactions as "externalities", while others believe that they are, in fact, externalities but can be ignored. Finally, a third group of economists define such interactions as "positive externalities" that compensate "negative externalities" that occur due to transport activities".

In today's world, there are two leading international organizations that initiate and implement comprehensive environmental protection studies worldwide, which are United Nations and European Union. In addition to these two organizations, World Bank, OECD, Black Sea Economic Cooperation Organization and many more international and regional organizations also carry out activities to protect and improve environment. What lie behind the negative effects of environmental regulations on the economies of countries is the costs imposed on companies during the "internalization of externalities" process. The increases in prices due to 


\section{Demiryolu Mühendisliği}

environmental regulations (especially taxes) affect production demands, therefore the amount of production, and also create negative effects on employment and international competition [9].

Potential social costs of traffic congestion, accidents, environmental pollution, noise pollution and climate change account for the "external cost" of transport sector. According to a study conducted in EU, this cost accounts for $4.1 \%$ of GNP of European Union countries ( $2 \%$ due to traffic congestion, $1.5 \%$ traffic accidents, $0.6 \%$ air pollution and noise). Not surprisingly, road transport is responsible for $90 \%$ of this cost [10].

The decisions taken and implemented by European Union regarding transport policy are as follows: the provision of sustainability in transport and the use of alternative means of transport; the improvement of coordination and planning processes regarding transport infrastructure; encouraging environment-friendly transport means (railway and seaway); the use of public transport in local transport; implementing an environment-friendly technology for fuels and vehicles; encouraging environment-friendly and reasonable use of private cars; and having drivers obey the predetermined speed limits [11].

Neil Kinnnock, a former member of the commission responsible for European Union Transport Policy, explains the importance of transport in people's life by uttering the following quotation: "The time people spend on transport activities makes up a great percentage of the total time they have during the day. Most of us travel by our private cars, but what we only care is the financial cost of this travel for us. Unfortunately, we selfishly ignore the harm we give to the environment by using our private cars. In fact, the cost we really create is quite high when we consider the money spent on treatment of the illnesses due to air pollution and on reducing air pollution etc, let alone fixing and maintenance cost of the roads, and the working hours lost in case of traffic congestions" [10].

\section{Internalization of Externalities Created by Transport Sector}

Traditionally, it has been necessary to finance the costs emerging in transport sector due to two main factors; namely investment and operation. However, today there is a growing need to consider a third cost factor due to the externalities created by transport sector. Accordingly, certain steps have been taken to internalize certain externalities created by transport sector such as air pollution, environmental pollution, social inequalities, traffic congestion; and time wastes. In other words; there is a tendency to take "social marginal costs" into consideration while calculating these costs and to make users compensate for these costs and transfer this amount to already existing resources [12].

Since externalities are the main cause of failures in markets, it is crucial to develop necessary incentives to encourage decision makers to take such externalities into consideration. This process is called "internalization of the external effects of production" [13].

Increasing local and global pollution due to transport sector requires all these countries to take necessary actions and precautions regarding the situation. Especially, European Union countries give a special importance to the "internalization of externalities" in order to ensure sustainable mobility.

Although there are various market solutions regarding the internalization of externalities, it is necessary to have compensation alternatives since such solutions are insufficient especially due to transaction costs. The most effective power to ensure such compensations is government. It is often observed that governments implement regulatory tools - mainly economic and financial ones - to intervene and reduce externalities in local transport [7]. 


\section{Demiryolu Mühendisliği}

Investment and operation costs in transport system require a financing source that is sustainable and reasonable enough to meet the expenses. Since all sources needed cannot be acquired through taxes (or not fair to do so), it is necessary to make users pay for the services and infrastructure costs (or a certain amount of them) [12].

Certain approaches have been adopted to calculate social costs due to the effects of transport on environment and some methods have been developed accordingly. Social costs are highly likely to contribute to decision making processes regarding the transport system of a country or a region in accordance with the policies to be adopted. The methods used in social costs are mainly based on the determination of indirect effects or the calculation of the price to be paid to get rid of these negative effects [14].

It is vitally important to take into consideration all the measures so as not to give harm to valuable fields and natural resources while planning a transport route. When these details are ignored, not only natural balance is disturbed but also economic losses are observed. The ecosystem highly affects and is affected by the actions of environmental organizations, misuse of natural resources by individuals, and the destruction of valuable fields due to various reasons [15].

The fact that transport vehicles are occupying available free fields as parking lots are known to cause serious problems in urbanization and housing projects, which is considered as "social cost".

Publishing "European Union Transport Policy White Paper" in September 2001, European Commission based its strategies, for the first time, on customer demands and proposed a total of 60 precautions accordingly. In 2007, "Green Paper" was published by the commission, which deals with urban transport.

"The White Paper" is the first phase of a 30-year long strategy designed for sustainable transport, which is also crucially important so as to ensure sustainable development. In order to fulfil this strategy, the following problems should be solved immediately [16]:

- Internalization of external costs and especially considering environmental externalities during the pricing of infrastructure are outstandingly significant.

- In order to help European Union free from this economic stagnation, it is necessary to reconsider competition conditions to give railway transport a last chance to carry out shipping services.

- It is necessary to adopt a new approach to modernize public transport and reduce private car use to a reasonable level.

- What is important here is to reconsider what to apply in order to meet effectively the demands of customers regarding service quality and customer rights since transport services are getting more and more expensive.

It is acknowledged by many people that transport won't be sustainable unless the existing investment and transport models are revised and reconsidered. Following tools can be considered valid in increasing the percentage of railway use in transport services in accordance with the conditions of market economy [10].

As for the precautions stated in "White Paper", use of private car and public transport quality can be solved at national level; however, the necessary timing regarding airway and railway transport requires international coordination and synchronization.

Making transport service users pay for internal and external costs in any means of transport: Through investment costs, it is planned to determine internals costs such as road maintenance 


\section{Demiryolu Mühendisliği}

costs and operation costs for each transport type and develop new methods to make users pay for these costs to compensate the damages, at least, to a certain extent. This compensation should also be fair among different transport means. European Commission prepared "Green Paper" for that purpose.

- Determining certain standards regarding safety, social and environmental adaptation.

- Improving Combined Transport

Establishing a balanced and sustainable economic and social development across European Union requires the use of various economic and financial tools. On the other hand, it is also necessary to benefit from the techniques of economy science so as to predict benefits and losses in case of the presence or lack of intervention by the government regarding any activities harming environment [17].

The amount of energy used by transport sector is increasing $4 \%$ every year. In other words, the total amount doubles in every twenty years [18].

The customers pay a certain amount of tax for the fuel consumed during transport services. Similarly, individuals have to contribute to infrastructure costs to a certain extent. In other words, adopting new policies by implementing certain economic tools based on the motto "those who use or pollute pay for it" helps authorities to internalize such externalities. The economic tools are the most effective methods to change customers' choices regarding transport means and their behaviors in a way to encourage the use of sustainable means. It is possible to encourage green transport means by making them more convenient, more economical and more tempting with the help of appropriate taxation and pricing applications. Such methods might persuade customers to reconsider their preferences due to reduced cost in these services [19].

The costs paid by the individuals regarding infrastructure include the payments such as highway and bridge tolls, vehicle circulation tax and annual vehicle tax.

An economy in harmony with ecosystem contrasts with the polluting and damaging economy of today, which is mainly vehicle-centred and mainly based on disposition economy and fossil fuels [6].

\section{The Evaluation of External Cost in terms of Sub Sectors}

Expressing externalities in monetary terms is the most important condition to internalize external costs and to include them in the fares. However, external costs do not have any markets since they are not subject to trade like other goods and services. This situation, therefore, causes the problem that they cannot be priced. In practice, the most common method used in expressing externalities in monetary terms is to determine whether users are willing to pay for the costs they create, and later to determine an agreed price for those costs Within the framework of the projects in 4th and 5th Framework Programmes financed by European Union, new methods were developed to express external costs in monetary terms for different transportation means. These new methods have enabled authorities to calculate external costs figures in various European Union countries. Based on these calculations, road transport has been found to create relatively higher external costs compared to railway transport. It is crucial to internalize external costs emerging in the form of insufficient railway infrastructure systems, accidents, air and noise pollution. What should be considered here is that external costs in road transport system such as traffic congestion and traffic accidents considerably differ from those observed in railway transport systems such as insufficient infrastructure and railway traffic accidents. However; certain information and methods related to the internalization of externalities such as air pollution and noise pollution can be applicable for both sectors [20]. 


\section{Demiryolu Mühendisliği}

In Table 1, a classification of important constituents in railroad transportation sector in terms of internal and external costs is made.

Table 1. The taxonomy of cost factors in railway transport system

\begin{tabular}{|c|c|c|}
\hline & Internal Costs) & External Costs \\
\hline $\begin{array}{l}\text { Transport and } \\
\text { operation costs }\end{array}$ & $\begin{array}{l}\text { Fuel, vehicle-maintenance and ticket } \\
\text { printing costs }\end{array}$ & $\begin{array}{l}\text { The cost paid by other customers or the } \\
\text { society }\end{array}$ \\
\hline $\begin{array}{l}\text { Infrastructure Use } \\
\text { Costs }\end{array}$ & $\begin{array}{l}\text { Infrastructure costs compensated } \\
\text { through travel fares paid by customers }\end{array}$ & $\begin{array}{l}\text { Costs that cannot be compensated } \\
\text { partly }\end{array}$ \\
\hline $\begin{array}{l}\text { Costs due to } \\
\text { accidents }\end{array}$ & $\begin{array}{l}\text { Costs compensated by insurance } \\
\text { companies and costs of accidents } \\
\text { compensated by individuals themselves }\end{array}$ & $\begin{array}{l}\text { Costs due to accidents that cannot be } \\
\text { compensated (those required to be } \\
\text { compensated by others), administrative } \\
\text { costs and others such as towing etc. }\end{array}$ \\
\hline $\begin{array}{l}\text { Costs due to } \\
\text { insufficient } \\
\text { Infrastructure }\end{array}$ & $\begin{array}{l}\text { Cancellations and wasting valuable } \\
\text { time of individuals }\end{array}$ & $\begin{array}{l}\text { Delays / Time waste costs required to } \\
\text { be compensated by others }\end{array}$ \\
\hline $\begin{array}{l}\text { Environmental } \\
\text { costs }\end{array}$ & $\begin{array}{l}\text { Short terms costs directly affecting } \\
\text { individuals }\end{array}$ & $\begin{array}{l}\text { Long terms costs affecting whole } \\
\text { society and even next generations }\end{array}$ \\
\hline
\end{tabular}

\section{The Externalities Created by Turkish Transport System and the Internalization of these Externalities}

It is observed that in Turkey there is a growing political will stated in Development Plans so as to reduce the negative effects of transport sector on environment and climate change in accordance with predetermined transport principles. Accordingly, the preparation of "Strategic Transport Plan" to achieve the objective "establishing a balance among the means of transport" was accepted as a strategy that should be followed. In addition, it was suggested that combined transport should be developed which covers all transport sectors operating between Asia and Europe. Finally, it was stated that the studies initiated within the framework of the resolutions by the Council of European Ministers of Transport would be completed so as to include externalities in the costs and to take into consideration the social costs -which was reported to gain importance due to increasing awareness in environmental issues- during planning and project processes in transport sector. Although not examined under the title of transport separately, the necessity to take certain precautions to develop renewable alternative energy resources, to extend the consumption of these resources to larger areas was also highlighted in the report. Stated under the title of "energy", these precautions were mainly due to the attempts to protect the environment [19].

When considered in terms of reducing the negative effects of transport sector on environment and climate change, the following precautions are likely to bring positive results within the framework of the policies stated in Development Plans: establishing a balance in transport infrastructure and shipping; creating multi-modality and inter-modality; increasing the share of railway and sea transport in transportation sector; developing important harbours into logistic centres; increasing energy productivity in transport sector; preparing a Strategic Transport Plan across the country; developing Local Transport Strategies; and encouraging public transport, bicycle use and walking during commuting practices. As of the publishing of 7th Development Plan prepared in mid 1990s in Turkey, it has been emphasized that the effects of transport sector on environment should be considered as "external costs" and certain practices should be developed and applied to internalize these costs by making the users compensate for them. Similarly, 8th Development Plan clearly supports such a strategy by writing: "Economic costs of road transport users will be considered as external costs and determined according to each vehicle type". It is true that economic tools are not used in transport sector effectively and sufficiently in Turkey [19]: 


\section{Demiryolu Mühendisliği}

- A system integrated into the main economic tool - vehicle taxation system - has not been completely developed yet to encourage citizens to prefer vehicles with less greenhouse gas emissions.

- Fuel taxation system used in transport sector is not effective enough in encouraging green fuel use.

- Fuel prices are known to be effective in changing the preferences of users in terms of fuel use and even means of transport. However, this tool is not used effectively in Turkey, either.

- In addition to fuel prices, pricing regarding the use of transport infrastructure has not been planned in a way to reduce the demand for fuels emitting higher amount of greenhouse gasses and to encourage users to prefer sustainable and environment-friendly fuel types.

- Highway and bridge tolls are effective economic tools where such tools serve as a demand management tool as well. The prevailing principle in Turkey is "one who uses pay for it". In other words, there is no incentive for the vehicles polluting the environment less and those carrying relatively higher number of people. Similarly, taking lower tolls from the vehicles with less greenhouse gas emissions in accordance with the principle "one who pollutes pays" or "pays more" is not an approach preferred in Turkey.

As for urban transport, the following demand management methods are preferred [19]:

- In urban transport, parking fees are not determined according to "one who pollutes pays" principle. This method is not used in Turkey, either.

- Another method used in demand management is asking drivers to pay a certain amount of toll when entering to the city centre. Likely to be effective in reducing traffic congestion in the cities suffering from heavy traffic, this system has not been applied in Turkey yet since the prerequisite for the success of this system is to provide quality and extended public transportation in such cities.

- Another important issue to consider in managing demand in transportation sector is how public transport is priced. In order to encourage people to prefer public transportation, the following applications can be put into practice: using combined tickets and providing free transport through transfer facilities; providing opportunities for unlimited number of travels through daily and weekly ticket applications.

\section{Conclusion}

In today's world, road transport, especially private car use, constitutes a great percentage of transport sector. It is now acknowledged that road transport is quite effective in terms of speed and availability thanks to rapid developments in vehicle technologies; however, it creates considerable amount of external cost in terms of the effects it creates on environment, air pollution it causes and its traffic-related effects such as traffic congestion, accidents and time loss.

The dominance of road transport in transport sector results in vital and global damage on environment. Similarly, traffic congestion causes delays and time loss. Although physical damages due to traffic accidents are compensated by insurance companies for individuals, there is no price to pay for those who were killed in traffic accident, since they cause considerable grief and sadness for the individuals and the society as whole.

The harms given by transport sector to the environment in the form of air, water and soil as well as noise and visual pollution cause considerable costs for both individuals and the society as a whole, which cannot be easily compensated.

During transport planning processes, in addition to considering the positive contributions of transport services to a country, region and city - for example by making it possible to organize cultural activities and events in the area- all possible external effects should be considered and 


\section{Demiryolu Mühendisliği}

these plans should be fulfilled by spending the lowest possible amount for the well-being of the country.

The failure in eliminating the negative effects of transport activities, in other words, the failure in the internalization of externalities is mainly due to the failure in integrating environmental policies with economic and social policies and using potential economic tools effectively.

The current study is likely to start a discussion on the adoption of combined policies and to lead the initiation of necessary processes so as to ensure sustainable transport. External costs emerging in this important service sector leads to inefficient use of economic resources, destruction of non-renewable energy resources and inequalities in the distribution of income.

- In order to eliminate externalities, it is necessary to replace the traditional transport mentality, which is highly dependent on private car use, with a new one which is considered as an economic activity giving importance to fair and environment-friendly practices.

In order to protect those affected by these externalities created by transport sector, the following practices should be applied:

- To apply "internalization of externalities methods" such as imposing certain restrictions and standards and forcing the authorities to take necessary precautions.

Compensating the harms given to those affected by these externalities, investment and operation costs in transport system requires a financing source that is sustainable and reasonable enough to meet the expenses. Since all sources needed cannot be acquired through taxes (or not appropriate to do so), it is necessary to make users pay for the services and infrastructure costs (or a certain amount of them) [12].

\section{Kaynakça}

[1] Y. Candemir, "Transportation education and training: in the world and in turkey," Proceedings Book of 6th Transportation Congress, TMMOB Chamber of Civil Engineers, İstanbul, Turkey, 2005, pp.110-129. [Online]. Available: http://www.imo.org.tr/resimler/ekutuphane/pdf/3190.pdf, [Accessed 06.04.2020].

[2] A.E. Bakırc1, "Examination of constituents of vehicle operation costs, establishment of saving perspective," Proceedings Book of 6th Transportation Congress, TMMOB Chamber of Civil Engineers, İstanbul, Turkey, 2005, pp. 395-404. [Online]. Available: http://www.imo.org.tr/resimler/ekutuphane/pdf/3190.pdf, [Accessed 06.04.2020].

[3] A. Kabasakal ve A. O. Solak, "Economic efficiency analysis of railway and road transportation systems," Anadolu University Journal of Social Sciences, vol. 10, no. 1, pp.123-136, 2010.

[4] M. Kaynak, Development Economics, Gazi Bookstore, Ankara, 2007.

[5] C. N. Berberoğlu, "Environmental pollution problem from the economic perspective," Eskişehir ITIIA Journal, vol.1, no. 2, pp. 219, 1982.

[6] L.R. Brown, Eco-Ecology: Building on Economy for the Earth. TEMA Foundation Publication, No:42, 2003.

[7] S. Benk, "Urban transportation based negative exteriorities and prevention methods," Ph.D dissertation, Dept. Graduate Schools and Institutes, Department of Public Finance, Uludağ Univ., Bursa, 2007.

[8] H. Zeybek, The Importance of Pricing in the Transportation Sector in the Improvement of Sustainable Development. United Nations - ESCAP Turkey Country Report, 2000.

[9] A. Z. Yalçın, "Evaluation of global environmental policies from the perspective of global public goods," Ballkesir University Journal of Social Sciences Institute, vol:12 no:21, pp.288-309, 2009. [Online]. Available:http://sbe.balikesir.edu.tr/dergi/edergi/c12s21/makale/c12s21m18.pdf [Accessed 16.02.2020].

[10]TUBITAK, "High Speed Train Report", [Online]. Available: http://kentvedemiryolu.com/yuksekhizli-tren-tubitak-raporu/, [Accessed 04.03.2020].

[11]M. Nalçakan, "Importance of Rail Freight in Transportation Sector in terms of Turkey's Economy and Analysis of Domestic Railway Freight Transport Demand by Econometric Model (Period 


\section{Demiryolu Mühendisliği}

between 1980 and 2000)," Ph.D dissertation, Social Sciences Institute, Anadolu Univ., 2003, Eskisehir.

[12]E. Öncü, "Financing and pricing policies in transportation," TMMOB, Transportation Policies Congress, 16-17 October 2003, İstanbul, Turkey, pp. 67-80. [Online]. Available:http://www.imo.org.tr/resimler/ekutuphane/pdf/12163.pdf [Accessed 04.03.2020].

[13] R. G. Lipsey, P. O. Steiner, D. D. Purvis, Economy I. (Translation: Ö.F. Batırel et.al), Bilim Teknik Press, Eskişehir.1984.

[14]TUBITAK-TTGV, Transportation Sector Report. Science Technology Industry Discussions Platform, Clean Fabrication - Clean Product - Environment Friendly Technologies Working Group, Ankara, 2002.

[15]DPT, 8th BYKP Transportation (Specialized Commission) ÖIK Report. (Railway Transportation Sub-commission), Ankara, 2001.

[16] CEC White Paper, "European transport policy for 2010: time to decide", White paper, Publications of the Commission of the European Communities, Brussels, 2001. [Online]. Available: http://www.central2013.eu/fileadmin/user_upload/Downloads/Document_Centre/OP_Resources/EUtransportpolicy2010_en.pdf, [Accessed 10.12.2010].

[17] E. Ferhatoğlu, "Environmental Taxes within the Framework of the Common Environmental Policy in the European Union". [Online]. Available: http://www.econturk.org/Turkiyeekonomisi/cevre_vergisi.pdf, [Accessed 28.10.2010].

[18] Istanbul-City and Transport Planning Commission Report (Draft), 1st Istanbul Urban Transport Meeting Report. İstanbul, 2002.

[19]E. Babalık-Sutcliffe, "Development of Action Plan of Turkey's National Climate Change Project, Transportation Sector Current Situation Assessment Report (2nd draft-Web)", September, 2010). [Online],Available:

http://iklim.cob.gov.tr/iklim/Files/Ulastirma_Sektoru_Mevcut_Durum_Degerlendirmesi_Raporu.pdf, [Accessed 01.03.2020].

[20] A. Taban, Railway Infrastructure Pricing and Freight Transportation in Turkey, Republic of Turkey, DPT. General Directorate of Relations with the European Union, Publication no: DPT:2796, Ankara, 2009.

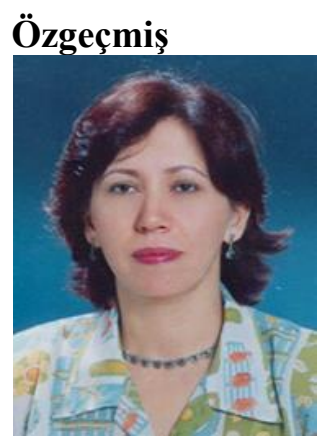

\section{Meserret NALÇAKAN}

1963'de Eskişehir'de doğdu. Gazi Üniversitesi İ̈BF İktisat Bölümü'nden mezun oldu. Anadolu Üniversitesi'nde 1989'da Yüksek Lisans; 2003'de Doktora eğitimini tamamladi. 2018'de Doçent oldu. Ulaştırma Ekonomisi, Ulaştırma Sektörü, Demiryolu İşletmeciliği, Demiryolu Lojistiği alanında yayınları bulunmaktadır. Eskişehir Teknik Üniversitesi Ulaştırma Meslek Yüksekokulu'ndaki Raylı sistemler alanında verilen eğitim programlarında öğretim üyesi; Ulusal Raylı Sistemler Test ve Araştırma Merkezi (URAYSIM) Projesi'nde araştırmaci; Ulaştırma Meslek Yüksekokulu'nda 2012'den beri Müdür Yardımcısı olarak görev yapmaktadir.

\section{Beyanlar}

E-Posta:mnalcakan@eskisehir.edu.tr

$\mathrm{Bu}$ makalede bilimsel araştırma ve yayın etiğine uyulmuştur.

Tüm yazarların eşit oranda katkısı olmuştur. 